\title{
APLIKASI EDIBLE COATING PADA BAKSO AYAM
}

\section{Edible Coating Application on Chicken Meatballs}

\author{
Muhamad Firmansyah \\ Program Studi Pendidikan Teknologi Agroindustri, Fakultas Pendidikan Teknologi dan Kejuruan \\ Universitas Pendidikan Indonesia, Bandung, Indonesia \\ E-mail: muhamadfirmansyah@upi.edu
}

\begin{abstract}
ABSTRAK
Bakso sangat digemari oleh masyarakat Indonesia, karena rasanya enak dan dapat dimakan oleh berbagai kalangan masyarakat. Bakso memiliki masa simpan yang pendek yang hanya bertahan 1 hari pada suhu ruang dan 2 hari pada suhu dingin karena termasuk perishable food yang mudah terkontaminasi oleh mikrobia saat proses penyimpanan. Salah satu cara untuk memperpanjang masa simpan bakso dengan menggunakan edible coating penambahan antimikroba. Metode yang digunakan dalam penelitian ini adalah studi literatur, berupa analisis artikel ilmiah dari berbagai jurnal yang bersumber dari google scholar yang membahas edible coating pada bakso dengan penambahan anti mikroba. Hasil dari literatur review ini menunjukan bahwa subtitusi ediblecoating menggunakan agar-agar dengan penambahan ekstrak jahe sebagai antimikroba dapat mempertahankan masa simpan bakso pada suhu ruang maupun suhu dingin. Pada penambahan konsentrasi agar-agar dan ekstrak jahe semakin tinggi konsentrasi keduanya maka dapat mempertahankan masa simpan bakso lebih lama dari aspek $\mathrm{pH}$ maupun total mikroba.
\end{abstract}

Kata kunci: bakso ayam, edible coating

\section{ABSTRACT}

Meatballs are very popular with the people of Indonesia, because it tastes good and can be eaten by various groups of people. Meatballs have a short shelf life that only lasts 1 day at room temperature and 2 days at cold temperatures because it includes perishable food that is easily contaminated by microbes during the storage process. One way to extend the shelf life of meatballs is by using an edible coating with the addition of antimicrobials. The method used in this research is the study of literature, in the form of analysis of scientific articles from various journals sourced from Google Scholar that discusses edible coatings on meatballs with the addition of anti-microbial. The results of this review literature show that the substitution of ediblecoating using agar with the addition of ginger extract as an antimicrobial can maintain the shelf life of meatballs at room temperature and cold temperatures. With the addition of agar concentration and ginger extract, the higher the concentration of both, it can maintain a longer shelf life of meatballs from the aspect of $\mathrm{pH}$ and total microbes.

Keywords: chicken meatballs, edible coating

\section{PENDAHULUAN}

Bakso sangat digemari oleh masyarakat Indonesia, karena rasanya enak dan dapat dimakan oleh berbagai kalangan masyarakat. Selain itu pembuatan bakso yang cukup mudah dan ditinjau dari segi gizinya, bakso juga memiliki nilai gizi tinggi. Bakso memiliki masa simpan yang pendek karena termasuk perishable food yang mudah terkontaminasi oleh mikrobia saat proses penyimpanan. 
Bakso tanpa bahan pengawet hanya memiliki masa simpan maksimal satu hari pada suhu kamar. Hal ini karena bakso memiliki kandungan gizi tinggi, yang terdiri atas kadar protein minimal $9 \%$, kadar lemak maksimal $2 \%$, kadar air maksimal $70 \%$, dan kadar abu maksimal 3\% (SNI 01-3818-1995). Karena kandungan gizi, nilai $\mathrm{pH}$, serta kadar air yang tinggi pada daging menyebabkan produk bakso memiliki masa simpan yang relatif singkat, umumnya umur simpan bakso hanya mencapai 12 jam atau maksimal 1 hari selama penyimpanan di suhu ruang (Sugiharti, 2009).

Salah satu cara untuk memperpanjang masa simpan bakso dengan cara yang aman adalah dengan menggunakan edible coating. Coating didefinisikan sebagai bahan lapisan tipis yang diaplikasikan pada suatu produk makanan. (Cuq dkk., 1995). Menurut Kenawi dkk., (2011), edible coating dari kemasan biodegradable merupakan teknologi baru dalam pengolahan pangan yang dapat berperan untuk memperpanjang masa simpan. Edible coating berasal dari bahan baku yang mudah diperbaharui seperti campuran lipid, polisakarida, dan protein, yang berfungsi sebagai barrier uap air, gas, dan zat-zat terlarut lain serta berfungsi sebagai carrier (pembawa) berbagai macam ingridien seperti emulsifier, antimikroba danantioksidan, sehingga berpotensi untuk meningkatkan mutu (Lin dan Zhao, 2007). Studi literatur ini meliputi edible coating yang dikombinasikan dengan penambahan antimikroba contohnya seperti senyawa yang bersifat hidrofobik yaitu ekstrak jahe karena memiliki sifat antimikrobia. Keuntungan penambahan bahan aktif selain meningkatkan daya simpan juga memiliki sifat penghalang yang diperkuat komponen antimikrobia sehingga dapat menghambat bakteri pembusuk pada bakso. Bahan utama untuk Edible coating pati, aquades hingga $100 \mathrm{ml}$, gliserol $2 \%$ dan antimikroba. Studi literatur review ini adalah untuk mengetahui karakteristik bakso ayam yang diberi edible coating dengan penambahan antimikroba selama penyimpanan pada suhu berbeda yaitu pada suhu dingin $4^{\circ} \mathrm{C}$ dan pada suhu ruang $23^{\circ} \mathrm{C}$.

\section{METODE PENELITIAN}

Metode yang digunakan dalam pada artikel adalah studi literatur, berupa analisis artikel ilmiah dari berbagai jurnal yang bersumber dari google scholar. Artikel yang dianalisis memuat hasil studi tentang edible coating dengan penambahan antimikroba untuk memperpanjang masa simpan bakso ayam pada suhu ruang maupun suhu dingin.

\section{HASIL DAN PEMBAHASAN \\ Bakso}

Bakso merupakan makanan berbasis protein yang digemari oleh semua lapisan masyarakat namun tergolong pangan dengan karakteristik mudah rusak sehingga masa simpan bakso pendek yaitu maksimal 24 jam pada suhu ruang (Sugiharti, 2009). Prinsip pembuatan bakso adalah penghancuran daging, pembuatan adonan, dan pemasakan. Bahan baku bakso selain daging adalah tepung tapioca, es batu, bumbu dapur seperti merica, bawang putih, dan garam dapur (Wicaksono, 2007). Bakso apabila disimpan lebih dari 24 jam pada suhu ruang mengalami kerusakan dipengaruhi oleh kandungan gizi yang kompleks sehingga dapat memberikan peluang bagi mikrobia untuk beraktifitas. 
Hal ini dapat terlihat dengan adanya perubahan populasi mikrobia sebagai agen perusak dan perubahan kandungan nutrisi sebagai sumber energi untuk aktivitas mikrobia, serta perubahan $\mathrm{pH}$ akibat penyimanan pada suhu ruang yang mempengaruhi laju penuruhan $\mathrm{pH}$. Banyak upaya yang telah dilakukan untuk memperpanjang daya simpan bakso seperti penggunaan pengawet sintetis berbahaya seperti boraks dan formalin yang dapat mengancam kesehatan. Maka dari itu untuk memperpanjang masa simpan bakso dengan cara yang aman adalah dengan menggunakan edible coating dengan penambahan antimikroba untuk mempertahankan masa simpan bakso tersebut.

\section{Edible Coating}

Edible coating merupakan lapisan tipis transparan yang terbuat dari bahan yang dapat dimakan dan dibentuk dengan menyalut produk yang berfungsi sebagai penghalang perpindahan massa (seperti uap air, gas, zat terlarut, dan cahaya). Edible coating dapat diaplikasikan dengan beberapa cara antara lain metode pencelupan (dipping), pembusaan, penyemprotan (spraying), penuangan (casting), dan penetesan terkontrol (Winarti dkk., 2012). Metode yang digunakan pada bakso ayam adalah metode pencelupan (dipping) karena metode ini sering digunakan pada buah dan daging dengan cara dicelupkan kedalam larutan yang digunakan sebagai bahan coating.

Metode pencelupan (dipping) mempunyai keuntungan seperti hasil coating yang lebih tebal, mempermudah proses pengcoatingan dan viskositas larutan bisa disesuaikan. Materi polimer penyusun edible coating bersifat aman, bahan yang dapat dimakan, dibentuk dengan menyalut produk yang diletakkan diantara komponen produk yang berfungsi sebagai penghalang perpindahan massa seperti uap air, gas, zat terlarut, dan cahaya (Warsiki dan Nurmala, 2013). Edible coating merupakan salah satu teknik pengawetan pangan yang relatif baru dengan bahan pengemas yang aman (Winarti dkk., 2012).

Pengaplikasian edible coating pada bakso dengan cara pati atau agar-agar ditimbang sesuai konsentrasi yang dibutuhkan dan ditambahkan aquades hingga $100 \mathrm{ml}$. Proses homogenisasi dengan pemanasan suhu $75^{\circ} \mathrm{C}$ serta pengadukan selama 10 menit dengan menggunakan magnetic stirrer. Selanjutnya dilakukan pendinginan hingga mencapai suhu $35^{\circ} \mathrm{C}$ sekaligus penambahan gliserol $2 \%$ dan antimikroba kemudian diaduk kembali supaya homogen (Triwarsita dkk., 2013).

Penerapan edible coating dapat mempertahankan kualitas dan memperpanjang masa simpan dari berbagai produk makanan (Hui, 2006). Pada kenyataannya lapisan dari pati memiliki kelemahan mudah rapuh karena sifat penghalang yang rendah terhadap uap air karena sifat hidrofilik dari pati (Winarti dkk., 2012). Tidak hanya pati saja yang bisa digunakan untuk melapisi edible coating bisa juga menggunakan agar-agar karena agaragar termasuk kedalam kelompok hidrokoloid berpotensi sebagai edible coating karena mampu mencegah respirasi dan kerusakan. Hal tersebut berkalitan dengan hidrokoloid memiliki ketahanan yang baik terhadap gas $\mathrm{O}_{2}$ dan $\mathrm{CO}_{2}$, dan dapat meningkatkan kekuatan fisik (Andriani , Nurwantoro, \& Hintono, 2018). Penambahan antimikroba pada edible coating merupakan salah satu upaya untuk memperbaiki karakteristik edible coating, dapat dilakukan dengan penambahan senyawa yang bersifat hidrofobik salah satunya penambahan bahan aktif yaitu ekstrak jahe sebagai pemberi kesan pedas dan sekaligus memiliki sifat antimikrobia. Keuntungan penambahan bahan aktif selain meningkatkan daya simpan juga memiliki sifat penghalang yang diperkuat komponen antimikrobia sehingga dapat menghambat bakteri pembusuk.

e-ISSN: 2541-4593 http://ejournal.upi.edu/index.php/edufortech 


\section{Pengaruh Edible Coating Terhadap Kualitas Bakso Ayam}

Aplikasi edible coating pada bakso ayam digunakan untuk memperpanjang masa simpan pada bakso ayam mengetahui kualitas bakso agar dapat diperpanjang masa simpannya ada beberapa indikator yang harus dilihat contohnya $\mathrm{pH}$, jumlah mikroba dan organoleptik yang terdapat pada bakso. Salah satu indikator pertama adalah $\mathrm{pH}$ yang dapat menentukan kualitas produk bakso, nilai pH berdasarkan Standarisasi Nasional Indonesia yaitu berkisar antara 6,0-7,0 (Firahmi, Dharmawati, \& Aldrin, 2015).

Pengukuran $\mathrm{pH}$ bertujuan untuk mengetahui tingkat keasaman bakso yang disebabkan oleh ion hidrogen $(\mathrm{H}+)$. Produk akhir yang mengalami pemasakan dan penggaraman bergantung pada $\mathrm{pH}$ daging. Temperatur tinggi meningkatkan laju penurunan $\mathrm{pH}$, sedangkan temperatur rendah menghambat laju penurunan $\mathrm{pH}$ (Sudrajat, 2007). Semakin lama penyimpanan memberikan pengaruh terhadap penurunan nilai $\mathrm{pH}$ bakso.

Indikator selanjutnya adalah total mikroba yang dapat dihitung melalui metode TPC (Total Plate Count) menurut Jay (2005) peningkatan jumlah mikroba dan pertumbuhan mikroba terjadi dalam waktu singkat pada kondisi tersedianya nutrisi seperti air, protein, lemak, vitamin, dan mineral sebagai sumber energi untuk berkembangbiak, selain itu salah satu faktor terpenting mengapa jumlah mikroba dapat meningkat karena dipengaruhi oleh lamanya penyimpanan, suhu dan kadar air.

Indikator terakhir adalah organoleptik, pada umumnya metode organoleptik digunakan oleh konsumen, untuk penilaian sensorik kualitas daging, khususnya warna, aroma dan kenampakan.Uji organoleptic dilakukan dengan menggunakan penelis untuk menilai mutu makanan atau minuman kemasan akibat pengaruh daya simpan. Uji ini dianggap paling praktis dan lebih murah biayanya. Namun disisi lain terdapat kelemahan diantaranya terdapat variasi produk dan variasi kelompok konsumen yang mungkin tidak bias terwakili oleh penelis. Penelis yang berasal dari laboratorium sering lebih bersifat kritis dan mempunyai kecenderungan menilai lebih rendah terhadap produk tersebut (Leni, 2008).

\section{1. $\mathrm{pH}$}

Pada umumnya pH pada bakso 6 hingga 7 untuk standar SNI yang sudah ditetapkan apabila kurang dari standar tersebut bakso dinyatakan tidak layak dikonsumsi oleh masyarakat. Pada penelitian yang dilakukan oleh Rakhmawati, S. Y., \& Handayani, M. (2019) pengamatan nilai $\mathrm{pH}$ bakso ayam sampel kontrol dan coating tanpa anti-mikroba menggunakan agar-agar dengan penambahan VCO (Virgin Coconut Oil) memiliki nilai pH sebesar 6,10 pada hari pertama, nilai tersebut sesuai menurut literatur yang disebutkan oleh Anggadireja (2007) menyatakan bahwa pH netral berkisar antara 6 hingga 6,5. Kemudian dihari kedua diperoleh nilai $\mathrm{pH} 5,88$ untuk sampel non-coating dan $\mathrm{pH} 5,75$ untuk sampel coating. Hal ini menyebabkan bakso tidak layak dikonsumsi karena tidak memenuhi standar SNI yang sudah ditetapkan. Faktor tersebut terjadi karena penyimpanan suhu ruang $23^{\circ} \mathrm{C}$ dapat meningkatkan laju penurunan $\mathrm{pH}$ (Soeparno, 2010).

Penelitian yang dilakukan oleh Jay (2005) juga menyatakan bahwa nilai $\mathrm{pH}$ substrat cenderung menjadi asam dengan semakin meningkatnya temperatur apalagi melibatkan suhu ruang yang cocok untuk mikroba beraktivitas. Sedangkan nilai $\mathrm{pH}$ sampel pada penyimpanan suhu dingin $4^{\circ} \mathrm{C}$ dilakukan hingga hari ke-12 pada sampel non-coating di hari ke-4, 8, 12 diperoleh nilai $\mathrm{pH}$ masing-masing 5,$91 ; 5,83 ; 4,91$. Dari penelitian tersebut terdapat penurunan di hari ke-4 hingga ke-12 dan sudah tidak sesuai dengan batas SNI yang ditetapkan. Kemudian untuk nilai $\mathrm{pH}$ sampel yang diberi edible coating diperoleh nilai pH masing-masing 6,$41 ; 6,07 ; 5,78$. 
Sampel yang diberi edible coating pada hari ke-4 dan 8 masih dalam kisaran $\mathrm{pH}$ yang sesuai dengan SNI dan menurun pada hari ke-12 tidak sesuai standar SNI. Penyebab penurunan nilai $\mathrm{pH}$ pada bakso tersebut menurut Muchtadi dan Ayustaningwarno (2010) menyatakan bahwa dengan terpecahnya karbohidrat (pati, pektin atau selulosa), maka bahan pangan dapat mengalami pelunakkan. Terbentuknya senyawa asam dapat menurunkan nilai $\mathrm{pH}$ dan terbentuknya gas-gas hasil pemecahan yang dapat mempengaruhi bau dan cita rasa.

Untuk mengatasi hal tersebut harus dilakukan penelitian lebih lanjut dengan penamabahan ekstrak jahe pada edible coating bakso daging ayam yang nantinya dapat menambah masa simpan bakso tersebut. Pada penelitian Afiqoh, U. N (2018) sampel bakso ayam yang telah diberi edible coating dengan penambahan ekstrak jahe pada suhu ruang $23^{\circ} \mathrm{C}$ dapat melindungi bakso hingga hari ke-2 dengan perlakuan terbaik dengan penamabahan komposisi pati $4 \%$ dengan ekstrak jahe 10\% menunjukan $\mathrm{pH}$ 6,0 yang dimana $\mathrm{pH}$ tersebut adalah batas aman dikonsumsi menurut standar SNI. Apabila masingmasing pati hanya diberi penambahan $2 \%$ dan ekstrak jahe hanya $5 \%$ didapatkan hasil $\mathrm{pH}$ 5 ,82, dimana $\mathrm{pH}$ tersebut tidak layak dikonsumsi menurut standar SNI. Hasil dari penelitian tersebut dapat disimpulkan nilai $\mathrm{pH}$ cenderung stabil seiring dengan meningkatnya konsentrasi pati singkong dan ekstrak jahe, karena kemampuan mikroorganisme dapat memanfaatkan komponen nutrisi seperti air, protein, lemak yang terhambat dan terbatas sehingga penurunan nilai $\mathrm{pH}$ dapat dikendalikan. Jadi semakin meningkatnya konsentrasi pati maka lapisan yang terbentuk menjadi semakin tebal, yang berfungsi sebagai penghalang perpindahan massa sehingga perubahan nilai pH dapat diminimalkan. Semakin meningkatnya konsentrasi ekstrak jahe juga dapat menghambat aktivitas mikrobia karena ekstrak jahe mengandung senyawa gingerol yang memiliki sifat antimikrobia. Perubahan nilai $\mathrm{pH}$ diduga karena adanya aktivitas mikroorganisme yang dapat mendegradasi senyawa komplek menjadi senyawa yang lebih sederhana. Pada penelitian Senoaji, F. B., Agustini, T. W., \& Purnamayati, L. (2017) dimana membahkan antimikroba seperti lengkuas dan jahe untuk memperpanjang masa simpan bakso daging ikan pada suhu dingin dengan nilai $\mathrm{pH}$ penambahan edible coating sebesar 6,22-6,33 di hari ke-15. Hal tersebut tentu dapat dikombinasikan dengan penambahan agar-agar sebagai subtitusi edible-coating untuk melanjutkan penelitian tersebut untuk diamati $\mathrm{pH}$ pada suhu dingin.

Pada penelitian Hadi et al. (2014) juga memperkuat pernyataan penelitian sebelumnya, dengan penurunan nilai $\mathrm{pH}$ seiring lamanya penyimpanan pada bakso daging kontrol, bakso daging yang diberi coating mengandung $1 \%$ kitosan atau yang diberi coating mengadung kitosan $1 \%$ dan penambahan ekstrak bawang putih $2 \%$ pada hari pertama. Penurunan $\mathrm{pH}$ dan terbentuknya bau busuk pada sampel bakso daging control dan yang diberi coating menunjukkan adanya aktivitas mikroba fakultatif anaerob. Setelah lebih dari 24 jam, maka edible coating akan rusak karena tak mampu menghambat keluarnya gas, uap air, dan kontak sampel dengan oksigen. Bakso merupakan suatu produk emulsi yang membutuhkan $\mathrm{pH}$ tinggi, diatas $\mathrm{pH}$ isoelektrik untuk kemampuan dalam mengikat air (Situmorang, 2013). Pada prinsip penambahan anti-mikroba pada edible coating memiliki dampak yang sama untuk memperpanjang masa simpan sama seperti halnya ekstrak bawang putih dengan ekstrak jahe tergantung dari berapa banyak penambahan anti-mikroba tersebut. Pernyataan tersebut diperkuat pada penelitian yang ditulis oleh Afiqoh, U. N. (2018) menunjukkan bahwa dengan penambahan pati dan antimikroba seperti ekstrak jahe dengan komposisi konsentrasinya ditingkatkan dapat mempertahankan $\mathrm{pH}$ bakso daging ayam lebih dari 24 jam dan kurang dari 48 jam. 


\section{Total mikroba dengan metode Total Plate Count (TPC)}

Total mikroba sangat perlu diketahui untuk dapat memastikan kelayakan suatu bahan pangan untuk dikonsumsi dengan metode Total Plate Count (TPC). Berdasarkan SNI 013818-1995, standar jumlah total mikroba untuk produk bakso maksimal sebesar $1 \times 10^{5}$ koloni/g atau sebesar $5 \mathrm{log} \mathrm{cfu} / \mathrm{g}$ (Wicaksono, 2007). Hasil penelitian menunjukkan terjadi peningkatan jumlah total mikrobia seiring dengan lama penyimpanan, selama penyimpanan bakso pada suhu ruang menyebabkan terjadinya kenaikan jumlah mikroba pada bakso secara cepat. Hal ini disebabkan oleh pengaruh suhu penyimpanan, yakni disimpan pada suhu ruang $\left(25-30^{\circ} \mathrm{C}\right)$ yang menguntungkan bakteri untuk tumbuh dan berkembang secara pesat. Salah satu menekan angka pertumbuhan mikroba dengan memperlambat laju perkembangannya pada suhu yang tidak optimum bagi mikroba yaitu pada suhu dingin $4^{\circ} \mathrm{C}$ yang mampu bertahan maksimal dua hari (Mahbub et al., 2012).

Pada penelitian yang dilakukan oleh Rakhmawati, S. Y., \& Handayani, M. (2019) untuk sampel bakso suhu ruang $23^{\circ} \mathrm{C}$ hanya dilakukan hingga hari ke-2 untuk sampel kontrol maupun coating karena mikroba pada hari ke-2 sudah melewati batas SNI sebesar 5,77 log $\mathrm{cfu} / \mathrm{g}$ kontrol dan 5,58 log cfu/g. Pada hari pertama tidak dapat dihitung karena sampel berada dibawah range minimal koloni mikroba yang bisa dihitung. Range koloni mikroba yang dapat dihitung adalah koloni yang berjumlah $25-250$. Untuk suhu dingin $4^{\circ} \mathrm{C}$ dilakukan pengamatan hingga hari ke-8, pengamatan hari keempat nilai mikroba untuk sampel noncoating didapatkan hasil TPC sebanyak 5,73 log cfu/g dan sampel yang di coating 4,67 log $\mathrm{cfu} / \mathrm{g}$ yang mana jumlah koloni yang terkandung pada sampel tidak melebihi batas maksimal SNI yang artinya sampel masih layak dan pada hari ke-8 pada non-coating 5,84 log cfu/g (lebih dari batas $\mathrm{SNI}$ ) dan coating 4,83 log cfu/g (masih batas aman SNI). Alasan mengapa edible coating dapat mempertahankan masa simpan bakso hingga hari ke-8 adalah komponen edible coating yang digunakan adalah agar-agar. Agar-agar merupakan hidrokoloid alami yang diekstrak dari rumput laut kelas Rhodophyceae (alga merah) berfungsi untuk mencegah transfer kelembaban, oksigen, rasa dan kandungan minyak antara makanan dan sekitarnya. Agar-agar juga merupakan hidrokoloid yang memiliki ketahanan yang baik terhadap gas $\mathrm{O} 2$ dan $\mathrm{CO} 2$, dan dapat meningkatkan kekuatan fisik (Andriani et al., 2018).

Pada penelitian Afiqoh, U. N (2018) pada hari ke-2 pada perlakuan terbaik yaitu pati $4 \%$ dan ekstrak jahe $10 \%$ pada hari ke-2 didapatkan hasil $7,0 \times 10^{5} \mathrm{koloni} / \mathrm{g}$, hal /tersebut sudah melebihi batas SNI yang telah ditetapkan. Sesuai dengan Jay (2005) yang menyatakan bahwa peningkatan jumlah mikroba dan pertumbuhan mikroba terjadi dalam waktu singkat pada kondisi tersedianya nutrisi seperti air, protein, lemak, vitamin, dan mineral sebagai sumber energi untuk berkembangbiak. Hasil penelitian menunjukkan bahwa semakin meningkatnya konsentrasi penggunaan pati singkong dan meningkatnya konsentrasi penambahan ekstrak jahe menunjukkan jumlah mikroba semakin kecil. Hal ini mengindikasikan bahwa ekstrak jahe untuk mempertahankan dan melindungi produk terhadap mikroba semakin besar, sehingga pertumbuhan mikroba terhambat dan akhirnya populasi semakin kecil. Seiring dengan meningkatnya konsentrasi pati maka terjadi peningkatan penghambatan terhadap pertumbuhan mikrobia. Hal ini karena lapisan dari pati berfungsi untuk menurunkan aw permukaan sehingga pertumbuhan mikrobia dapat diminalkan. Semakin meningkatnya konsentrasi ekstrak jahe juga terjadi penghambatan terhadap pertumbuhan mikrobia. 
Sesuai dengan Nursal dkk. (2006) menyatakan bahwa ekstrak jahe memiliki senyawa metabolit sekunder golongan fenolik yang merupakan golongan senyawa bioaktif yang dapat menghambat pertumbuhan mikrobia. Kemampuan dari fenol dapat mendenaturasi protein dan merusak membrane sitoplasma, ketidakstabilan dinding sel dan sitoplasma menyebabkan protein sel bakteri terganggu.

Hasil penelitian Neetoo dkk (2010) yang melaporkan bahwa pelapis alginat dapat menunda pertumbuhan Listeria monocytogenesis pada fillet salmon asap dingin suhu simpan $4^{\circ} \mathrm{C}$ dan keefektifan pelapis antimikrobia dalam menghambat pertumbuhan mikroba tergantung pada konsentrasi antimikrobia yang ditambahkan. Lu dkk. (2010) juga menyampaikan bahwa pertumbuhan mikrobia pada filet yang dilapisi alginat dengan inkorporasi cinnamon selama penyimpanan (suhu $4^{\circ} \mathrm{C}$ ) mengalami penghambatan, akibatnya mutu filet dapat dipertahankan. Hal ini memperkuat pernyataan bahwa semakin meningkatnya konsentrasi penambahan ekstrak jahe yang diberikan maka semakin besar penghambatan bakteri. Sedangkan, semakin meningkatnya konsentrasi penggunaan pati atau subtitusi agar pada edible coating maka zona bening yang terbentuk semakin kecil. Hal ini terjadi diduga karena semakin tinggi konsentrasi pati maka viskositasnya akan semakin meningkat sehingga edible yang terbentuk akan semakin tebal. Penambahan ekstrak jahe pada edible coating sebagian terikat oleh bahan penyusun yaitu pati sehingga aktivitas ekstrak jahe akan kurang maksimal.

\section{Uji Organoleptik}

Hasil dari beberapa penelitian diatas menunjukkan bahwa seiring lama waktu penyimpanan maka nilai aroma semakin menurun. Perubahan nilai aroma selama penyimpanan disebabkan oleh perubahan sifat pada bahan pangan yang mengarah pada penurunan mutu. Sesuai dengan Estiasih dan Ahmadi (2009) yang menyatakan bahwa selama penyimpanan terjadi reaksi kimia dan aktivitas mikroba tetap berjalan yang mengakibatkan perubahan bau dan rasa. Untuk penambahan ekstrak jahe pada edible coating mengalami peningkatan nilai aroma yang segar dan agak tajam dari produk. Hal ini dapat disimpulkan penambahan edible coating dengan penambahan anti-mikroba seperti ekstrak jahe dapat menambah nilai jual terhadap bakso tersebut dan pada penilaian uji organoleptik terhadap kenampakan bakso yang dilakukan oleh panelis terjadi penurunan. Hal ini terjadi terjadi karena pati pada coating dan anti-mikroba pada edible coating mampu mempertahankan tekstur mutu bakso selama penyimpanan akibat aktivitas mikroba yang memberikan efek melunaknya bakso sehingga nilai kenampakan semakin turun. Pada penilaian organoleptic terhadap warna, bakso yang diberi coating dengan berbagai konsentrasi memberikan kesan pelapisan tidak terlalu tipis dan tidak terlalu tebal serta memberikan kesan mengkilat dan terlihat lebih cerah dan kesan pelapisan tidak terlalu mencolok dengan adanya penambahan antimikroba seperti ekstrak jahe yang berwarna kuning keemasan.

Dari penelitian pengujian organoleptic yang dilakukan oleh beberapa penelitian diatas dapat diambil kesimpulan bahwa penggunaan edible coating pada bakso ayam dapat diterapkan dan digunakan untuk masyarakat umum karena dilihat dari hasil pengujian organoleptik tersebut mendapat kesan positif dan menjadi nilai jual tersendiri karena dapat meningkatkan aroma serta aroma yang disukai konsumen dan dapat mempertahankan tekstur bakso ayam agar tidak mudah melunak apabila disimpan pada suhu ruang dan suhu dingin. 


\section{KESIMPULAN}

Subtitusi edible-coating menggunakan agar-agar dengan penambahan antimikroba seperti ekstrak jahe dapat mempertahankan masa simpan bakso pada suhu ruang maupun suhu dingin. Pada penambahan konsentrasi agar-agar dan ekstrak jahe semakin tinggi konsentrasi keduanya maka dapat mempertahankan masa simpan bakso lebih lama dari aspek $\mathrm{pH}$ maupun total mikroba.

\section{DAFTAR PUSTAKA}

Afiqoh, U. N. (2018). Aplikasi Edible Coating Berbasis Pati Singkong Dengan Penambahan Ekstrak Jahe (Zingiber Officinale Var. Amarum) Untuk Mempertahankan Kualitas Bakso Daging Pada Penyimpanan Suhu Ruang (Doctoral dissertation, University of Muhammadiyah Malang)..

Andriani , E., Nurwantoro, \& Hintono, A. (2018). Perubahan Fisik Tomat Selama Penyimpanan Pada Suhu Ruang Akibat Pelapisan Dengan Agar-Agar. Jurnal Teknologi Pangan, 176-182.

Anggadiredja, J.T., Zatnika, A., Purwoto, H., dan Istini, S., (2002). Rumput Laut, Penebar Swadaya, Jakarta

Arief, H. S., Pramono, Y. B., \& Bintoro, V. P. (2012). Pengaruh edible coating dengan konsentrasi berbeda terhadap kadar protein, daya ikat air dan aktivitas air bakso sapi selama masa penyimpanan. Animal Agriculture Journal, 1(2), 100-108.

Chrismanuel, A., Pramono, Y. B., \& Setyani, B. E. (2012). Efek Pemanfaatan Karaginan Sebagai Edible coating Terhadap pH, Total Mikroba dan H2S Pada Bakso Selama Penyimpanan 16 Jam. Animal Agriculture Journal, 286-292.

Cuq, B., Gontard, N., dan Guilbert, S. (1995). Edible Films and Coatings as Active Layers. In: Active Food Packaging. Blackie Academic and Professional, Glasgow, United Kingdom

Estiasih, Teti dan Kgs Ahmadi. (2009). Teknologi Pengolahan Pangan. Bumi Aksara. Malang.

Fardiaz, S. (1992). Mikrobiologi Pangan I. Jakarta: Gramedia Pustaka Utama.

Hadi, H. N. S., Suyatma, N. E., \& Syarief, R. (2014). Aplikasi Kitosan dengan Penambahan Ekstrak Bawang Putih Sebagai Pengawet Dan Pelapis Edibel Bakso Sapi (Chitosan Application with Addition of Garlic Extract as a Preservative and Meatballs Edibel Coating). Jurnal Sains Terapan, 4(1).

Hui, Y. H. (2006), Handbook of Food Science, Technology, and, Engineering Volume I. CRC Press, USA

Jay, J.M. (2005). Modern Food Microbiology. Seventh edition. Springer Science and Business media

Kenawi, M. A., M. M. A. Zaghlul, dan R. R. Abdel-Salam. (2011). Effect of Two Natural Antioxidants in Combination with Edible Packaging on Stability of Low Fat Beef Product Stored Under Frozen Condition. Biotechnology in Animal Husbandry. 27(3): 345-356.

Lin, D. dan Zhao, Z. (2007). Innovations in the development and application of edible coatings for fresh and minimally processed fruits and vegetables. Comprehensive Reviews in Food Science and Food Safety 6: 60-68

Mahbub, M. A., Pramono, Y. B., \& Mulyani, S. (2012). Pengaruh edible coating dengan konsentrasi berbeda terhadap tekstur, warna, dan kekenyalan bakso sapi. Animal Agriculture Journal, 1(2), 177-185

Moulia, M. N., Syarief, R., Suyatma, N. E., Iriani, E. S., \& Kusumaningrum, H. D. (2019). Aplikasi Edible Coating Bionanokomposit Untuk Produk Pempek Pada Penyimpanan Suhu Ruang. Jurnal Teknologi dan Industri Pangan, 30(1), 11-19. 
Muchtadi, T. R. dan F, Ayustaningwarno. (2010). Teknologi Proses Pengolahan Pangan. Alfabeta, Bandung

Nasional, D. S. (1995). SNI 01-3818, Bakso Daging . Jakarta (ID): Dewan Standardisasi Nasional.

Neetoo, H., Ye, M. dan Chen, H. (2010). Bioactive alginate coatings to control Listeria monocytogeneson coldsmoked salmon slices and fillets. International Journal of Food Microbiology 136: 326-331

Nusral, Wulandari dan Juwita. (2006). Bioaktivitas Ekstrak Jahe (Zingiber officinale Roxb.) dalam Menghambat Pertumbuhan Koloni Bakteri Escherichia coli dan Bacillus subtilis. Jurnal Biogenesis.

Octavianie, Y. (2002). Kandungan Gizi dan Palatabilitas Bakso Campuran Daging dan Jantung Sapi. Bogor: Skripsi. Fakultas Peternakan IPB.

Putri, D. N., Anggita, C., Cahyanti, S., \& Monica, S. A. (2019). Aplikasi Oleoresin Rimpang Jahe Emprit Pada Edible Coating Sebagai Antibakteri Pada Bakso Daging Sapi. Food Technology and Halal Science Journal, 1(1), 64-71.

Rakhmawati, S. Y., \& Handayani, M. N. Aplikasi Edible Coating Berbasis Agar-Agar dengan Penambahan Virgin Coconut Oil (VCO) Pada Bakso Ayam. EDUFORTECH, 5(1).

Reynaldi, A., Rostini, I., Afrianto, E., \& Rochima, E. (2019). Pengaruh Penambahan Ekstrak Bawang Putih pada Lapisan Kulit Nila Berbasis Gelatin Terhadap Sifat Antimikroba dan Umur Bakso Ikan. World Scientific News , 134 (2), 74-85

Senoaji, F. B., Agustini, T. W., \& Purnamayati, L. (2017). Application of Essential Oils from Galanga Rhizome in Edible Coating Carrageenan as Antibacterial on Tilapia Fishball. Jurnal Pengolahan Hasil Perikanan Indonesia, 20(2), 380-391

Soeparno. 2010. IImu dan Teknologi Daging. Gadjah Mada University Press., Yogyakarta

Sudrajat, G. (2007). Sifat Fisik dan Organoleptik Bakso Daging Sapi dan Daging Kerbau dengan Penambahan Karagenan dan Khitosan. Bogor: Skripsi. IPB.

Sugiharti, S. (2009). Pengaruh Perebusan Dalam Pengawet Asam Organik Terhadap Mutu Sensori Dan Umur Simpan Bakso. Bogor: Skripsi. Fakultas Teknologi Pertanian. Institut Pertanian Bogor.

Suradi, K. (2006). Perubahan Sifat Fisik Daging Ayam Broiler Post Mortem Selama Penyimpanan Temperatur Ruang (Change of Physical Characteristics of Broiler Chicken Meat Post Mortem During Room Temperature Storage). Jurnal Ilmu Ternak, 23-27.

Triwarsita, W. S. A., Atmaka, W., dan Muhammad, D. R. A. 2013. Pengaruh penggunaan edible coating pati sukun (Artocarpus Altilis) dengan variasi konsentrasi gliserol sebagai plasticizer terhadap kualitas jenang dodol selama penyimpanan. Jurnal Teknosains Pangan 2(1): 124-132

Wariyah, C., \& Riyanto. (2018). Efek Antioksidan dan Akseptabilitas Bakso Daging Ayam Ras dengan Penambahan Gel Lidah Buaya. Agritech, 125-132.

Warsiki, E., Sunarti, T. C., \& Nurmala, L. (2013). Kemasan Antimikroba untuk Memperpanjang Umur Simpan Bakso Ikan. Jumal IImu Pertanian Indonesia, 126131.

Wicaksono, D. A. (2007). Pengaruh Metode Aplikasi Kitosan, Tanin, Natrium Metabisulfit dan Mix Pengawet Terhadap Umur Simpan Bakso Daging Sapi Pada Suhu Ruang

Winarti, C. (2013). Teknologi produksi dan aplikasi pengemas edible antimikroba berbasis pati. Jurnal Penelitian dan Pengembangan Pertanian, 31(3)

Yulianti, T., \& Cakrawati, D. (2017). Pengaruh Penambahan Ekstrak Daun Salam Terhadap Umur Simpan Bakso. AGROINTEK, 37-44. 